\title{
The Networked Handling of Rush Orders in Customer Services
}

\author{
Per Engelseth \\ Troms $\varnothing$ Business School \\ University of Troms $\varnothing, 9037$ Troms $\varnothing$, Norway \\ E-mail: pen008@uit.no (Corresponding Author) \\ Brian E. White \\ Complexity Are Us Systems Engineering Strategies \\ Sudbury, Massachusetts, USA \\ E-mail, bewhite71@gmail.com
}

\begin{abstract}
Rush orders are characterised by time constraints and organisational priority. They are handled by the supplier with the aim of meeting customer requirements in as limited a timeframe as possible. Rather than focusing on rush orders as a deterministic planning problem, this paper takes an interorganisational perspective that highlights the complex networked interactions between the supplier and the customers. In this single case study of an advanced sanitary product supplier, rush orders involve process prioritisation concerning both: (i) supplies of in-stock parts that are delivered with preset time objectives; and (ii) parts not in stock that must be quickly fabricated. This supply process is highly emergent, in that unexpected events or properties occur. This study considers the difficulties of determining and dealing with root causes, unexpected effects, and interventive solutions for rush orders. This operational level of analysis provides a foundation for advocating the application of complex systems thinking to solve or at least significantly mitigate the problem of rush orders. It also contributes to and advances further research on this subject.
\end{abstract}

Keywords: rush orders, spare parts supply, networking, customer services, complex systems.

\section{INTRODUCTION}

Supplier-relationship management, often termed sourcing, includes the issue of how to strategically handle orders that are relatively unplanned. Rush orders are received by the supplier with time constraints as the main classifying factor. The limited timeframe indicates a need to adapt in order to manage this type-classification of supply. Wang and Chen (2008) provide a systemic framework from a singlefirm perspective, and apply a neo-fuzzy-based forecasting approach that describes how to manage rush orders by pointing out various causes and corresponding methods, including: implicit customer priority; concern for extra returns, outlays, and usuries; special orders authorised by higher-ups; and production disturbances. This time constraint classification indicates that from the viewpoint of the focal firm managing downstream logistics to its customers, rush orders are not limited to technical discrepancies, and may also be caused by marketing or managerial factors, for instance. Wang and Chen (2008) also describe three methods for use in solving the rush-order problem: (i) improvement in forecast accuracy; (ii) approaches to better receive and handle rush orders; and (iii) a mechanism to increase reserve capacity for queuing requests. Since uncertainty is one of the prime features of customer relationships, forecasting systems are limited in terms of detecting emerging issues related to both supply demand and its technical provision, although they provide valuable management indicators for directing supply-related activities.

The main limitation of Wang and Chen's (2008) approach is that it implies a deterministic, single-firm focus rather than a complex, networking-sensitive approach. This study attempts to understand supply-process coordination as a complex system embedded in supply-chain management (SCM) thinking (Cooper et al., 1997, Mentzer et al., 2001). This implies a fundamental view of rush orders as both an inter- and an intra-organisational problem. In addition, this study ultimately seeks to consider how such rush orders must be treated as a complex phenomenon in this SCM context.

SCM implies that the analytical focus is directed toward the features of supply-chain integration and collaboration in order to coordinate rush orders as supply processes, rather than toward information system (IS) technicalities (Cooper et al., 1997, Halldorsen et al., 2003, Kouvelis et al., 2006, Halldorsen et al., 2007). This is in line with Ketchen and Hult's (2006) recommendation to apply streams of thinking from organisation theory to conceptually develop operations management (OM) and find improved, practical business solutions. When viewed as a complex entity, a "supply chain" conceptually implies the view that management is more preoccupied with achieving connectivity and capacity for adaptation rather than weaning the organisation away from the perceived managerial threat of rush-order problems, in a deterministic fashion. Following Rzevski and Skobelev's (2014) understanding of complex systems, the organisational challenge is to develop the sensitivity of emerging processes so as to better navigate the complexity of supply chain networks. The empirical findings of this study include a description of the industrial network of a high-tech sanitation product supplier. Its customers are mainly industrial, with its products mainly found on ships, aeroplanes and trains, but to a limited extent, it also supplies products to individual consumers in locations that have limited access to plumbing. This supplier receives rush 
orders, making it the focal firm in this single-case study.

The following three issues are covered from the perspective of this firm, in order to empirically ground the way in which rush orders are handled by the firm's customer services department:

- How do rush orders occur?

- What impacts do they have?

- What could be done to improve the current situation? Together, these research issues contribute to collect data and thus describe the as-is situation of the firm, focusing on the relationships it has with the customers generating the rush orders. However, this does not exclude the potential for interactions with its own suppliers to solve the rush order problem. In addition to answering these questions, this study seeks to highlight the potential of complex systems thinking as a solution to organising rush orders at this firm

\subsection{Rush Orders}

\section{LITERATURE REVIEW}

Yao and Liu (2009) classified two types of orders. Special orders come from one enterprise, with a specified time threshold, and are associated with specialised orderfulfilment procedures. All other types of orders are general orders. Rush orders are classified as special orders. Trzyna et al. (2012) provide a technical definition of a rush order as "an order that did not arrange within time of the current schedule placed in a very short time of delivery, and need to be handled in a very short period of time." As previously indicated, time is the defining characteristic that differentiates a rush order from standard orders. Trzyna et al. (2012) and Yao and Liu (2009) discuss the contemporary need to develop a more precise understanding of what the term "rush order" really means. They point out that the time threshold is a decisive feature of this process, including the impact on the organisational surroundings. Although time is necessarily short in cases of rush orders, where is the boundary between a general order and rush order? This concern is elaborated upon and discussed in this case study. There are also concerns about how rush orders are prioritised. Yao and Liu (2009) explain "The orders that should be given the highest priority to operate to fit the urgent delivery date of customer are named Rush Order (RO) which are not restricted by the time threshold." This implies that organisational urgency is more important than technical time limitations when processing a rush order in logistics practice.

\subsection{Customer Services and Planning}

Rush orders are normally handled by the customer service function of a firm. Customer service is associated with interactions between the customer and supplier that are not associated with a transaction, which is handled by the purchasing and sales functions. Customer service supports the transaction of products and services. Gourdin (2006) argues that a firm's customer service strategy is built around five key concepts: (i) dependability; (ii) time; (iii) convenience; (iv) communication; and (v) honesty. A prime goal of customer service functionality is to achieve customer-responsive supply relationships in order to secure trust, which is expressed as loyalty in a business relationship. Chopra and Meindl (2010) argue that supply-chain responsiveness involves the ability to:
- $\quad$ Respond to wide ranges of demand quantities

- Meet short lead times

- Handle a large variety of products

- Build highly innovative products

- Achieve a high level of service

- Handle supply-chain uncertainty.

In business practice, rush orders are typically fundamentally associated with uncertainty, making it challenging to plan them in detail. This is due to a lack of spare parts planning, including limitations on the cost of holding spare parts. Wang and Chen (2008) seek to use advanced forecasting programs to help solve this planning problem. Svensson and Barfod (2002) argue that a failure to get the right material at the right time is one main reason why rush orders are placed. If a general order has not been correctly filled, a rush order is needed to follow up on this, and when material is missing, planned orders are delayed. Svensson and Barfod (2002) refer to this as a simple but common problem that leads to delays in most cases. From the supplier's perspective, such problems can primarily be managed by the customer service function.

\subsection{Organising in Uncertainty}

Rush orders that suddenly preoccupy the supplier organisation are intertwined with uncertainty. According to Angkiriwang et al. (2014), demand uncertainty is: "The probabilistic nature of demand quantity, types, timing, and locations. Demand uncertainty could be in the form of errors in the demand forecast, changes in customer orders, uncertainty about the product specification/mix that the customers will order, and competitor actions regarding marketing promotion." However, this uncertainty also arises when the rush order is received by the supplier and in how the supplier organises its handling. The latter uncertainty concerns the entire organisation, implying that the organisation must be able to achieve quick and effective coordinate internal coordination.

A prioritised, ad-hoc form of organisation is required when the rush order is filled, since this is a special order requiring special handling (Yao and Lin, 2009). If such special organising is not planned, it must be developed as the order is received and filled. Plossl (1973) points to a relationship between rush orders and delays in standard orders, and Chen (2010) also argues that prioritising rush orders may generate delays in scheduling standard orders. Kim and Duffie (2004) describe how an increase in unplanned orders such as a rush orders can cause fluctuation in general lead times, and can significantly increase order backlogs and variability in material quality, due to poor fabrication coordination. In the same vein, Ehteshami et al. (1992) argue that rush orders decrease the level of service for standard orders, and can increase inventory and supply delays and the unpredictability of the production system. This indicates that management typically approach rush orders with a certain amount of anxiety, leading to a higher proportion of rush orders tying up logistics, which may result in insufficient customer service resources being devoted to standard orders. When a rush order appears received, all customer service hands, as well as management, are concerned with these orders, thus hampering normal supply activities. This implies the need to balance the organisation's resources between special and general orders. 


\subsection{Documentation and the Customer Voice on Product Criticality}

From a network perspective, exchange (which envelops information document sharing) is a key remedy in handling rush orders. It is also important to have the right documentation at the right time, to keep the flow of information smooth. According to Yan-Hai et al. (2005), missing documentation causes planning problems and poor logistical quality. This underpins the importance of having quality information that must be shared in the supply chain to execute the vital logistics of rush orders and implies a form of reciprocal interdependency in managing rush orders. Following Thompson (1967), reciprocal interdependency creates a need for management to mutually adjust production plans (in this case, the operational supply plans) through the business relationship. Since these are special orders, it cannot be taken for granted that the supplier will instantly understand the concept of the order, including how it is to be transported. The order may include a range of factors, such as goods, location, transport, payment and service options, all of which can be negotiated. The more special the supplier perceives the order to be, the more mutual adjustment may be needed to get the order right. This indicates the importance of developed business relationships in such cases to allow such complex interactions to be smoothly handled, implying that interaction plays a role in some cases of rush orders. How this exchange is carried out impacts the exchange economy of the supply chain (Hammervoll, 2014), so these management processes should be efficient as well as effective.

Rush orders may be defined in relation to the customer's perception of their criticality. This implies a value perspective, since it is associated with aspects of customer needs. According to Huiskonen (2001), criticality can be divided into process criticality and control criticality. Process criticality is related to the consequences of a failure when a replacement is not readily available, and the cost of production downtime is a major part of process criticality. Control criticality deals with the possibility of influencing production, involving features such as forecasting error, goods availability, lead times, and an array of logistical concerns. Criticality is strongly associated with customer perceptions of this lack of supply control or the consequences for production. When a rush order is received, a customer-responsive supplier will heed the customer's concerns by seeking to comply with their needs and deliver the goods in accordance with rush-order specifications. A lack of goods specificity affects complexity, since goods must be defined through interaction prior to supply. Demand patterns are associated with the degree of uncertainty of the order, involving important features such as the type, frequency and volume of goods. The customer's voice is also vital in rush orders, as it can convey the degree of criticality, affecting how the supplier should prioritise this order in a context of numerous rush orders and general orders.

\subsection{Networking to Prioritise Resource Use}

Various solutions have been proposed to improve handling rush orders. Simangunsong et al. (2011) provide a list of strategies for coping with the demand uncertainty that is typical of rush-order situations:
- Postponement

- Information sharing with downstream partners such as retailers

- Enhanced information and communication technology use

- Use of strategic buffer stocks

- Lead-time management.

Postponement may not intuitively appear to be a good fit for handling rush orders; however, the negotiated timing of supplies becomes an issue in cases when goods are out of stock. These different factors are complementary and can be used to varying degrees. They all involve strategic investment, variation and value, which can be analysed through considering costs and benefits. According to Davis (1993), variations in supply and demand can be evened out by using inventory as a buffering mechanism, although this solution implies an increase in inventory holding costs in order to satisfy the customer. Wang and Chen (2008) also mention this as a viable solution but suggest that the supplier could reserve some production capacity to handle rush orders. The supplier should also develop specific criteria for handling incoming rush orders, such as the size of the customer, the amount of product ordered, or the profit it would create. Yan-Hai et al. (2005) state that rescheduling the manufacturing system may help in supporting the ontime execution of both rush orders and standard orders. Tryzna et al. (2012) argue that work-in-progress inventory must be at an acceptable level, so that both rush and standard orders may be fabricated in a balanced manner when there are a large number of orders. Rush orders also represent a fabrication planning problem that should be taken seriously in advance, due to the delivery time, change in inventory level, and lack of capacity or need for it be rearranged. Finally, this understanding of fabrication planning includes taking into consideration the impact that these rush orders have on current and potential customer relationships.

In this case study, rush orders are associated with deliveries of spare parts. According to Fortuin and Martin (1999), companies may have a catalogue consisting of 100,000 spare parts, but only have 50,000 actually in stock. The remaining spare parts can be ordered but may need to be manufactured. This implies a need for supply postponement, a strategy that does not seem be a good fit for rush orders. Fortuin and Martin (1999) argue that there is a need for categorisation in order to identify which parts to stock. They provide the following list of spare-part delivery criteria:

- Reparability

- Demand intensity

- Purchasing lead time

- Delivery time

- Planning horizon

- Essentiality, vitality and criticality of a part

- Price of a spare part

- Costs of stock keeping

- Ordering/re-ordering costs.

Huiskonen (2001) proposes a simpler classification system involving only four control characteristics: criticality, specificity, demand pattern and parts value. This implies differentiating spare parts supplies in relation to these criteria, in regard to the effects they have on supply quality. 
This overview also involves the concept of product complexity, which includes service elements.

\subsection{Complexity and Research Issues}

Product complexity is considered as an aspect of fabrication, since a rush order may be associated with standard in-stock items to varying extents. The degree of product complexity affects how the goods to be supplied are technically produced. Closs et al. (2008) define product complexity as "from a multiplicity of elements, as well as from relationship among the elements," meaning that it can be organisationally challenging to keep track of all the elements of a production system. Blackenfelt (2001) describes product complexity as the number of parts and the relationships between the parts, but complexity can also be related to issues of product variety, since it directly affects complexity. As part of a supply-chain flow domino effect, the more complex a product, the greater the risk of a higher number of sub-suppliers, rendering the coordination of fabrication more challenging. A complex product may potentially be embedded in a more complex supply network. According to Svensson and Barfod (2002), traditional ways of producing a complex, highly customised product have shifted from material processing to competence in managing product information. Closs et al. (2008) argue that market diversity creates higher complexity due to increasing product variations. In order to handle this product complexity, Closs et al. (2008) note that managers may seek to limit requirements by balancing it with customer demands for supply adaptation. It is difficult to optimise any level of product complexity to ensure the right amounts of cost and revenue. Blackenfelt (2001) mentions modularisation as a compromise that can ensuring customer responsiveness and cost efficiency. Product design and information exchange are ways of handling product complexity in cases of relatively severely time-constrained supply.

In addition to product complexities, it is also vital to consider the complexity of the rush order process. In a supply system, complexity must be defined more broadly than product complexity. In this case, a product is a type of good associated with physical distribution, which is often viewed as a static artefact. However, the system is dynamic. From a process viewpoint, complexity is defined as "a property of an open system that consists of a large number of diverse, partially autonomous, richly interconnected components, often called agents, has no centralised control and whose behaviour emerges from the intricate interaction of agents and is therefore uncertain without being random" (Rzevski and Skobelev, 2014, p.5). Fundamental to this view is that conceptually enhancing complexity is the foundation for developing a complexity-sensitive way to manage rush orders, supported by complex systems software. Rezevski and Skobelev (2014) point out that the key features of complexity are openness, diversity, partial autonomy and interconnectedness of agents, a lack of centralised control, and emergence. This component interlinking entails interdependence, i.e. the ways in which the supplier and customer need each other and are complementary in the network. Management must consider how to handle processes in which components continually change in terms of not only time, place and form, but also how they are interconnected (pooled) and perceived. In a complex system, service is not only transformed in production, but the way in which it is evaluated may also change over time, affecting production. Interaction using flexible resources is important when considering rush order supplies as complex managerial processes. Interdependency is thus reciprocal and dependent on intense interaction to achieve mutual adaptation of the supply process (Thompson, 1967).

This study is concerned with elaborating the causes and effects of rush orders, and solutions for organising them. The above discussion reveals that complexity is a key feature of rush orders, and is a reciprocally interdependent, networked phenomenon in a sea of interdependencies. Rather than being dyadically limited to a single business relationship, it is a complex, and is a process that can be studied as an emerging phenomenon rather than as a deterministic planning problem.

\section{METHOD}

A single case study of rush orders was carried out, based on the general ideographic stance taken in this research. An ideographic stance implies a search for details of particular cases. As shown by Thomas (2011), the quality of a case study lies not in its validity or reliability, but particularly in its credibility (Lincoln and Guba, 1985). The quality of a case study is determined by a range of technical factors associated with the research process. Following Ellram (1996), a research protocol was used to track the progression of the study and enable us to look backward through the research process, referencing and comparing findings as they emerged. Iteration between theory and empirical findings was continuous in the context of the applied research protocol.

In the same vein as Yin (2003) and Thomas (2011), the choice of a general case study format was made in order to study the activation of rush orders in a real-life context by applying mixed methods. Qualitative interviews represented the main source of information, supplemented by observation and documents provided by the companies involved. Following Eisenhardt (1989), the aim of this qualitative research is not generalisation, but to empirically identify concepts related to understanding this phenomenon and to develop theory on this subject. Rather than empirical generalisation, which is commonly sought in quantitative research, we sought to enhance theoretical generalisation, in line with Meredith (1998). This means that findings could be made at higher levels of conceptual abstraction, as discussed by Lincoln and Guba (1985).

In accordance with Voss et al. (2002), the more specific choice of a single case study was used to search for details of rush orders in a single networked firm. If a multiple case study had been chosen, the aim would have been to compare the cases; in this study, a comparison is made by considering the elements of the empirical data in relation to each other and to theory provided in the preceding literature review.

The study began on $19^{\text {th }}$ January 2017 , when a semistructured group interview was conducted in Norwegian with six employees at the firm's main office. Two people from the research team took part in this visit. Our contact person was present throughout the interview. The chief operating officer (COO) was present during the first hour and 25 minutes, while the other participants were interviewed during the remaining hour and 35 minutes. Interviews were not 
conducted alone with each employee because of their busy schedules. Table 1 summarises those who took part in this first interview and the durations of their involvement.

Table 1 Informants and interview durations.

\begin{tabular}{|l|l|}
\hline Position in the company & Interview duration \\
\hline Production manager/Site manager & 2 hours and 30 minutes \\
\hline Chief operating officer (COO) & 1 hour and 25 minutes \\
\hline Manager aftersales and export & 1 hour and 35 minutes \\
\hline $\begin{array}{l}\text { Sales assistant - Land and } \\
\text { Transport }\end{array}$ & 1 hour and 35 minutes \\
\hline $\begin{array}{l}\text { Sales assistant - Land and } \\
\text { Transport }\end{array}$ & 1 hour and 35 minutes \\
\hline Export coordinator & 1 hour and 35 minutes \\
\hline
\end{tabular}

The contact person at the supplier studied here, a former production manager who now serves as the factory manager, arranged the interview for us and gathered employees involved with rush orders at a technical level. The group interview enhanced the inter-subjective nature of the meeting as a learning process. Although the interview guide organised the covered topics, providing a semi-structured frame, the encounter became freer over time, making it a learning experience for all involved. Inter-subjectivity has the objective of careful influence in order to reveal understanding through interactions in an interview (Thomas, 2011). Since this became a group interview, the interviewees complemented each other during the interview; they filled in information for each other and discussed their various perceptions of rush orders, often associated with handling different types of orders and customers. Another positive result from the group interview was that through careful guidance by the research team, the interviewees did not repeat themselves or overlap their responses. The interviewees exhibited good moods and were not afraid to help or correct each other during the interview. Mediation of this group interview was the responsibility of the two moderators from the research team.

This first interview was carried out at the stage in which the literature search was started. The purpose was to refine how the firm conceived of rush orders, thus enabling increased precision in the design of this research. This first group interview provided not only a valuable fundamental understanding of how the company perceived rush orders but also the challenges they posed to the organisation. It also provided an overview of the functions of the company and the firms with which it works in the supply chains. A list of potential informants among their customers was also provided.

After the interview, the contact person took us to the production and warehouse department, where we observed how production was performed. The contact person also showed us some of the products that had been discussed during the interview, so that we could get a clearer picture of what they had been talking about. Supplementary brief interviews were carried out with customers, represented by either domestic dealerships or representatives abroad. An adapted customer interview guide for dealers and representatives was created; this was sent in the same form by electronic mail (email) to these customers, and requests were made to carry out an interview using Skype. This was a lengthy interview guide, and we did not expect that the customers would agree to be interviewed. However, all the customer informants agreed to take part in the study, although they preferred to respond to our questions by email rather than by Skype. These customers were partially motivated by the fact that this research could help improve the handling of rush orders. The interviewees included four domestic retailers, and three international representatives located in Singapore, the United Arab Emirates, and Greece. Before we sent out the questions, our supplier contact person read and assessed the questions in order to ensure that they would not create relationship problems between the company and their customers.

The initial group interview was taped and transcribed, and this was followed up with additional questions by phone for clarification later in the research process. Among other things, the supplier informants were asked to reflect on the customers' replies. The group interview was transcribed, and notes on the additional telephone interviews were made. These transcripts and the emails from the customers were used to organise the replies, following the general frame of reference regarding rush orders and their causes, effects and solutions. Our analysis involved comparing the frame of reference to the empirical data, as well as comparing the different empirical sources with each other in an iterative manner. This provided grounds for recording the findings in a structured manner as the case description, followed by an analysis.

\section{CASE}

The case narrative on rush orders is divided into two parts: the first covers the supplier perspective, while the second covers the customer perspective.

\subsection{The Supplier Perspective}

The sanitary product supplier has two market segments in which they work, and these are organised into two departments: shipping and offshore, and land and transport. These segments consist of several different sub-segments, as shown in Table 2.

Table 2 Segment overview

\begin{tabular}{|l|l|l|}
\hline $\begin{array}{c}\text { Shipping and } \\
\text { offshore department }\end{array}$ & $\begin{array}{r}\text { Land and } \\
\text { transport } \\
\text { department }\end{array}$ & Miscellaneous \\
\hline Bulk and cargo & Cabins and homes & Research \\
\hline Cruise & Train & Internal sales \\
\hline Ferry & Discharge station & "Other" \\
\hline Offshore production & Building & \\
\hline Navy & Mobile solutions & \\
\hline Tanker & Bus & \\
\hline Yacht & Supermarkets & \\
\hline Fishing & Outdoors & \\
\hline Offshore supply & Land and transport & \\
\hline Ropax vessels & & \\
\hline Fast ferry & & \\
\hline
\end{tabular}

Research, Other, and Internal sales are segments located within the main segment. The Other segment is more general in character and includes functional aspects in both the Ship and offshore and Land and transport segments. The difference between a traditional sanitary product that uses gravity and a vacuum sanitary product is that the latter uses air instead of water to handle human waste; only a small amount of water is used to clean the bowl in a vacuum 
system. The company offers two different designs for their vacuum sanitary systems. The largest system is the constant vacuum system (CVS), which is for larger ships and buildings. This system can handle multiple toilets and can easily be expanded to increase capacity. The smaller system is vacuum-on-demand (VOD), which has a capacity of up to four toilets. This system produces a vacuum only at the moment the toilet needs to be flushed. A typical sanitary system supplied by the company consists of a toilet connected to a specialised vacuum pump, which is then connected to a collection tank, bio tank, biogas plant, treatment plant, or public sewage system.

The supplier has a network of domestic retailers and global representatives. Some of the foreign representatives support both the shipping and offshore segment and the land and transportation segment. There are 87 domestic dealerships, 85 of which deal only with systems for the cabins and homes segment. The other two deal with both the cabins and homes segment and the larger building segment. These dealerships are usually stores that carry sanitary systems and plumbing equipment for cabins.

The supplier did not have a formal, explicit definition of what they classified as a rush order, and perceived rush orders as one of the many services provided to its customers, without giving it much analytical thought. However, they had a conception of supply timing that was based on the lead time within which orders need to be filled. The customers placing these rush orders typically contact the sales or aftersales departments when they place such orders. These types of orders require a maximum of 48 hours to answer the customer's enquiry in the case where delivery is impossible the same day. Of the 8,506 orders placed in 2016, 682 or approximately $8 \%$ were classified as ad hoc rush orders. The invoice amount for rush orders was 3.8 million NOK, of a total invoice amount in 2016 of 246 million NOK. Of the 682 rush orders, 507 were delivered within Norway, and the remaining 175 were delivered to other countries, although some of the orders delivered within Norway were addressed to airports for shipping outside of Norway. Figure 1 provides an overview of the total number of rush orders, divided among the different organisational departments.
Figure 2 provides an overview of rush orders placed in 2016, divided into customer segments.

The main difference between handling a standard order and a rush order was the time between when the order was registered and when it was packed and shipped to the customer. In relation to handling fabrication orders and spare parts orders, one informant stated:

It is very important to separate fabrication orders from spare part orders, since the spare part orders each have a specific number of hours within which they should be completed and delivered. Approximately $90 \%$ of all these orders are spare parts, which need to be delivered within 48 hours. This makes it very difficult to run it smoothly over the whole year.

The main difference is that fabrication orders entail a production process that takes more time to fulfil. Since the product complexity varies, the time needed to fabricate a product that is ready for delivery may also vary. Rush orders therefore become an issue of prioritising production. Orders that are infrequent or demand certain degrees of tailoring are commonly subject to fabrication upon demand and are not found in stock. The supplier fabricates to stock only the most standardised and highest volume spares. The company mainly follows a pull flow production principle and aims to limit the made-to-stock inventory. Figure 3 provides an overview of the different types of orders generated by sales at the company.

Figure 3 shows the different processes used for orders. The land and transportation segment is more standardised than the ship and offshore segment, making it easier to produce systems for that segment. The ship and offshore segment supplies more customised solutions, since the sanitary systems need to fit vastly different ship configurations. Production for the ship and offshore segment is therefore more time-consuming. The order becomes a rush order when the customer has lead-time requirements that are shorter than the standards shown in Figure 3. Orders with spare parts dominate the rush orders. Figure 4 shows the relatively simple order-handling procedure for a spare part.

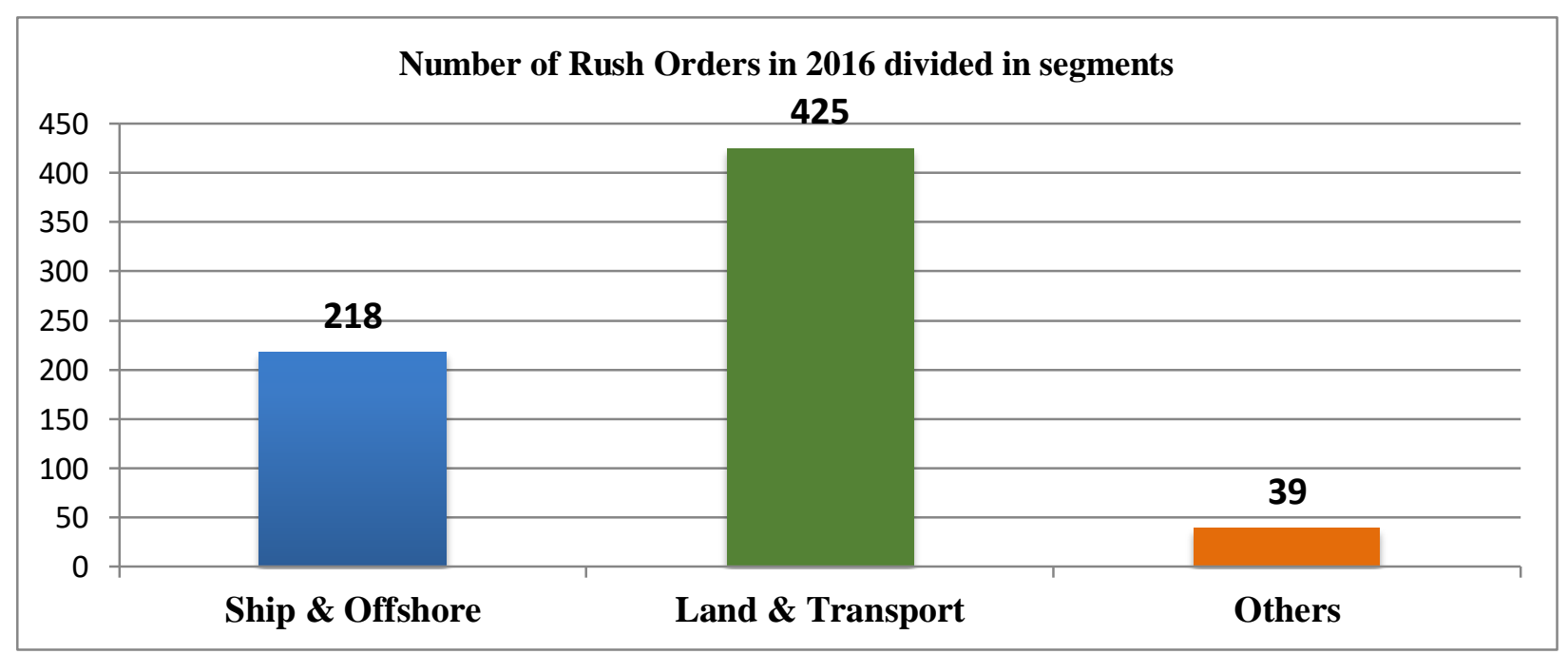

Figure 1 Total annual numbers of rush orders, divided among departments 


\section{Overview of rush orders placed in 2016 divided in segments}

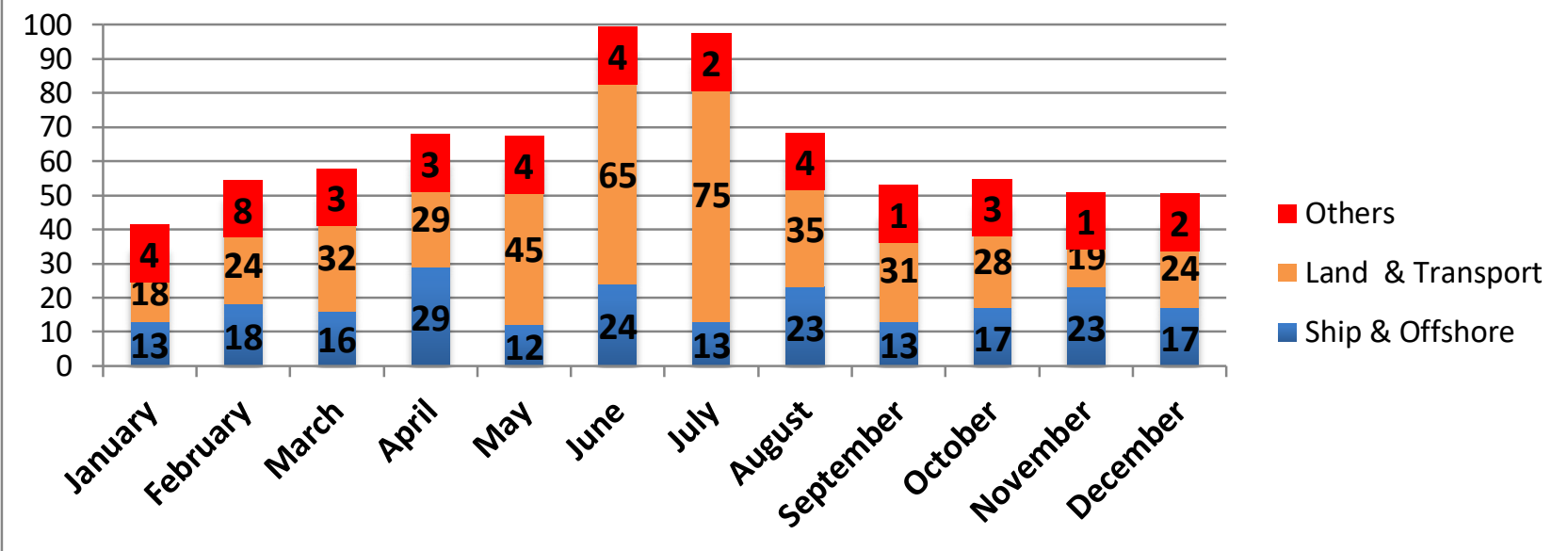

Figure 2 Rush orders received in 2016, divided among customer segments

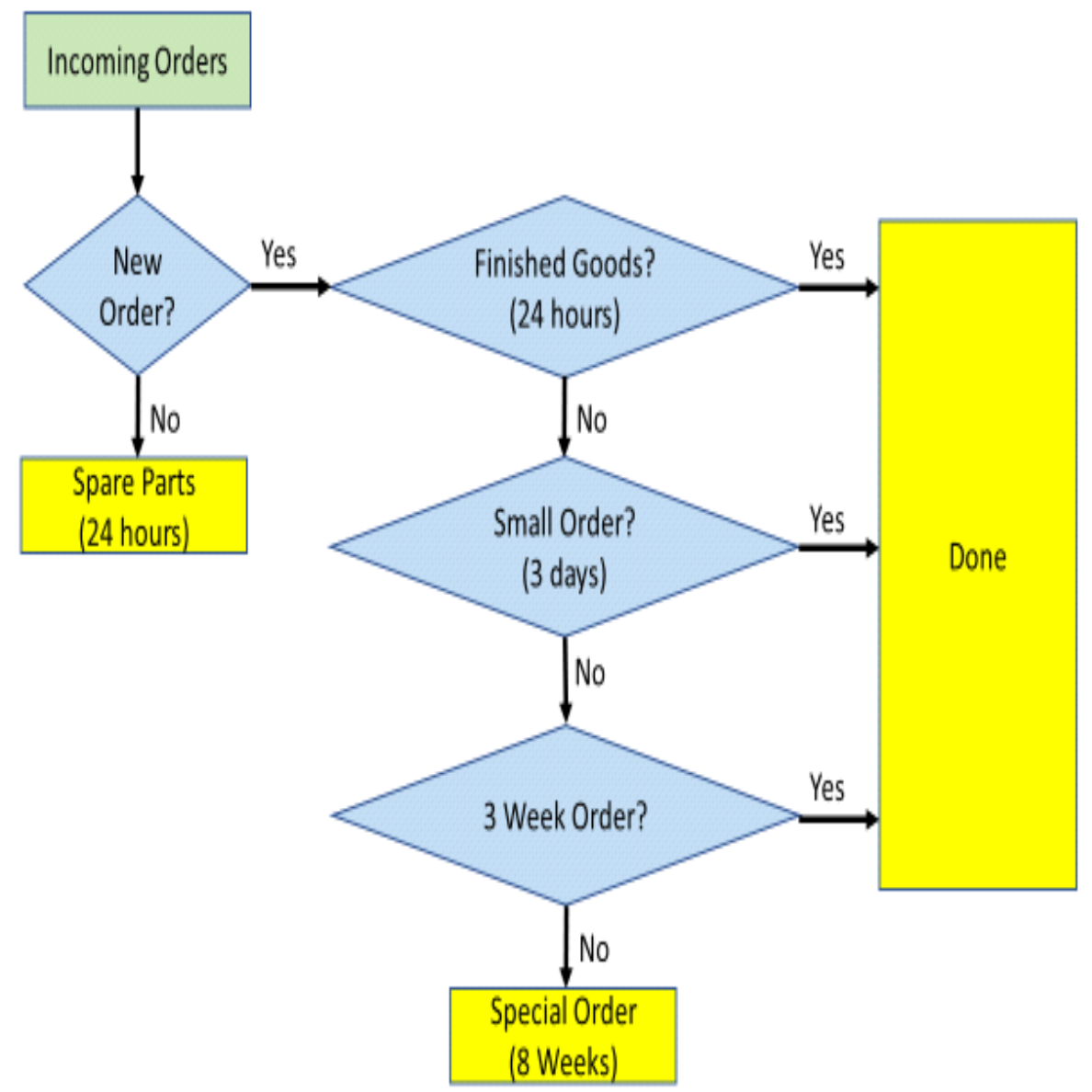

Figure 3 Standards relating to time for different types of orders after confirmation

\section{Registering} the order

\section{Packing}

\section{Shipping}

Figure 4 Standard procedure for handling a rush order for spare parts 
When a customer places an order for a spare part, the order is first registered; the order is packed the next day and shipped a day later. The customer usually places the order by email, and the supplier has a policy of answering the enquiry within 48 hours. One informant stated:

We receive an order from a customer by email on a Monday and we are in meetings all that Monday. We may also have received a lot of emails that same day. Then we will not manage to tend to all the received emails, including potential rush orders. Possibly the next day we will also be busy, and we may not manage to finish going through all the received emails. But then on Wednesday, we read it, meaning that two days have gone by before we have responded. Then we have to register the order on Thursday and send it on Friday.

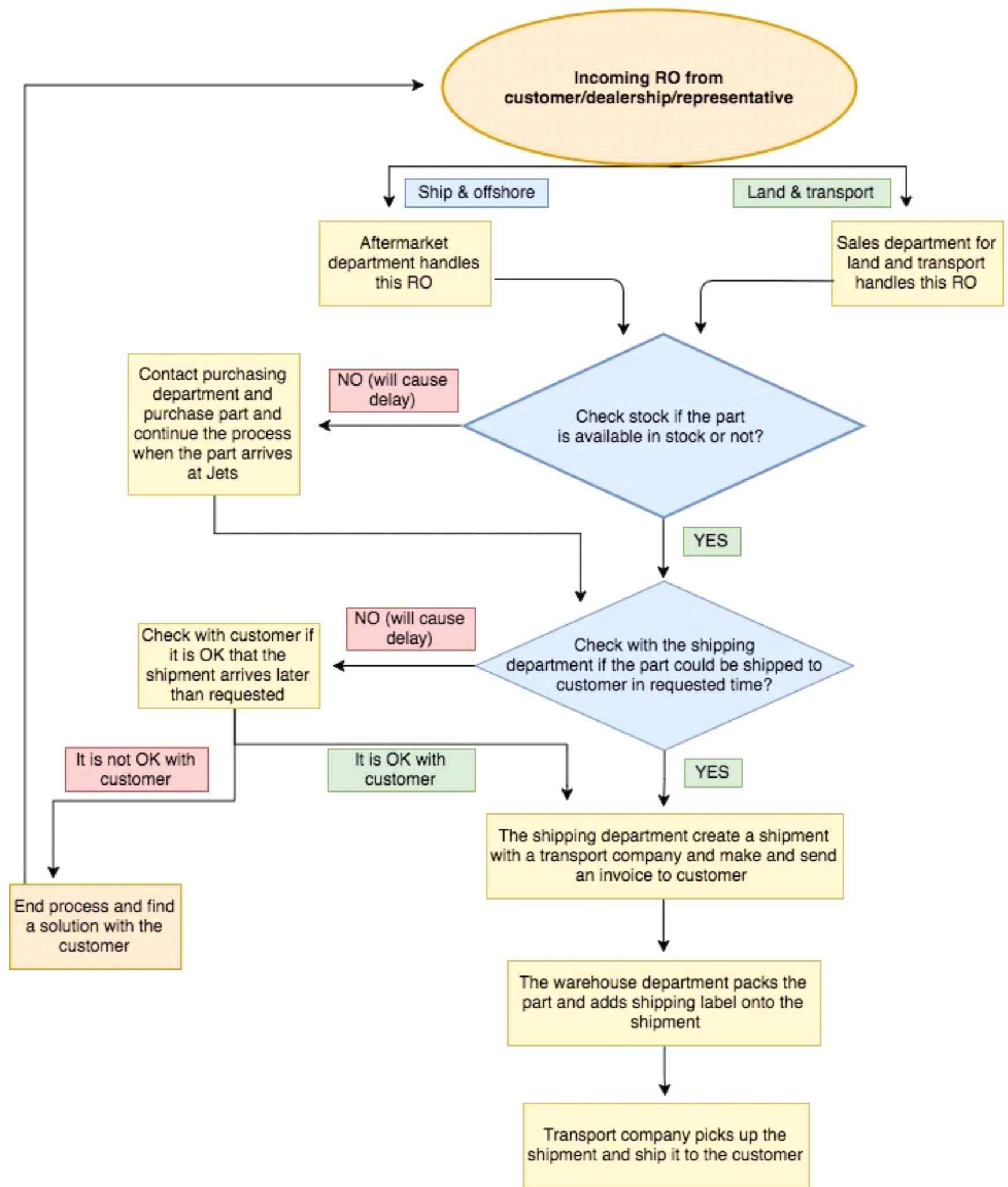

Figure 5 Rush order process for spare parts 


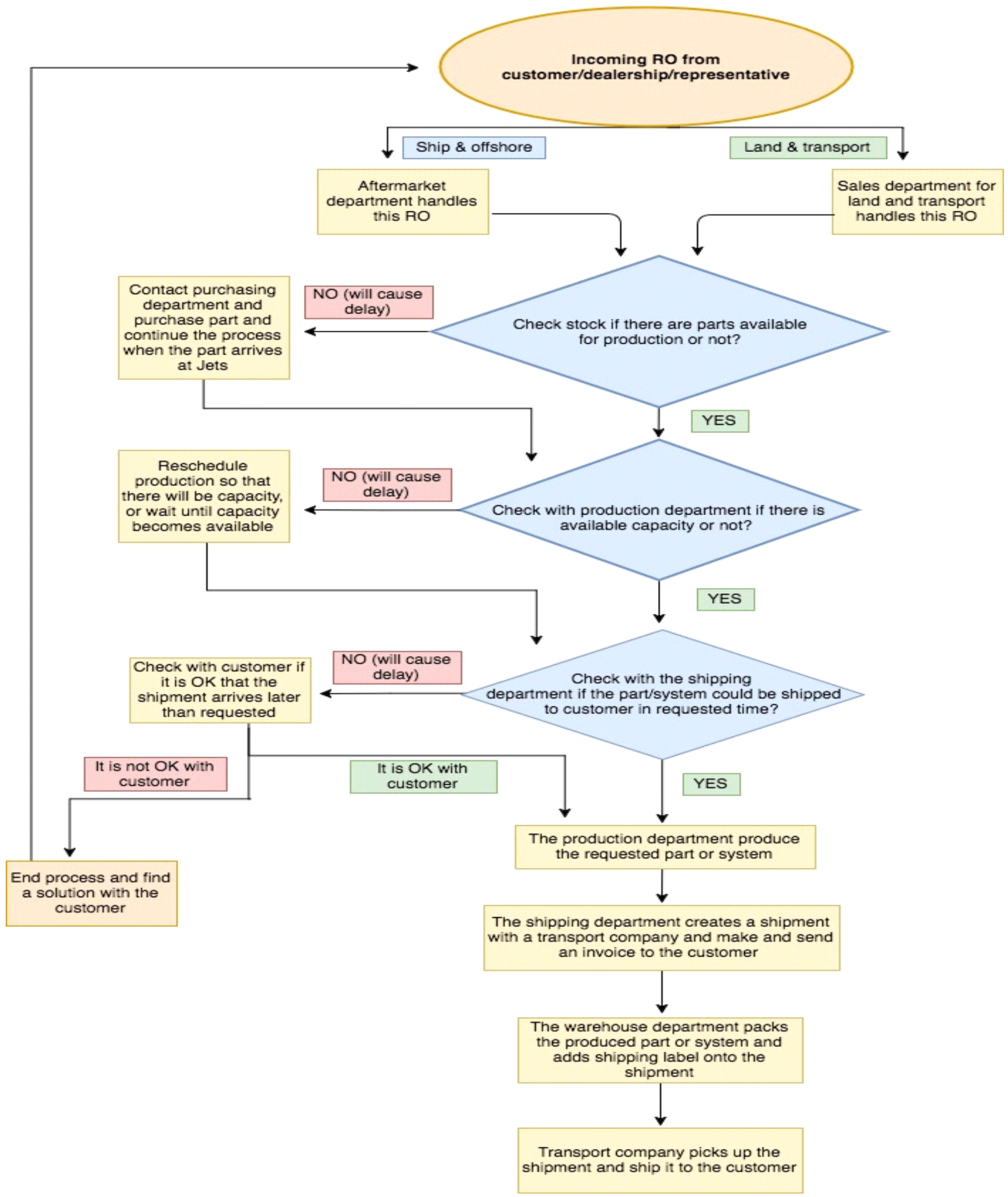

Figure 6 Rush order process for products requiring fabrication

The supplier must also check the inventory to see if the part is available when an order is received. The warehouse handling and logistics capacity and the point of destination must also be checked. An informant stated:

If a customer places an order for their ship in Singapore and the ship is scheduled to leave Singapore on a specific date, it is important to be able to send the spare parts to the customer before that date. If we see that the parts can arrive before that date, but we are still not $100 \%$ sure we can make it in time, we do not take that chance, and we therefore ask the customer to inform us of the next destination for the ship. We have no intention of sending the goods to Singapore and then missing the ship because it had already left. We would then have to start a new process of sending it to the next port of call after Singapore in the sailing plan.

This standard procedure was developed over the years due to the increasing numbers of incoming orders and the steps of the process through which the order must go. It 
would have been possible to pack and ship orders the same day 10 years ago; now, however, only rush orders are packed and shipped the same day. These are registered as zero days between when the order is registered and the finish date. This is the main difference between standard and rush orders. Figure 5 shows the rush order process for the supply of spare parts to customers.

When a rush order comes in, the customer often calls the supplier. Over time, employees have developed knowledge about the customers who place orders. When they call, it is often urgent. The first step indicates which department handles the rush order: the aftermarket department handles orders from customers within the ship and offshore segment, while the sales department handles orders from the land and transportation segment. It is important to understand some of the differences between these two main segments. Since the ship and offshore segment has greater production variety compared to the land and transportation segment, the handling process in the ship and offshore segment is sometimes more challenging. An informant said:

The product variation is immense. We have a product base of approximately 7000 different parts, and so the different possibilities for making a new product are huge. But, of course, this differs in the kind of segment one operates in - in the land and transportation segment, there are five to six different models with standard sets of parts. The product variation is much larger in the ship and offshore segment.

The next step is to use the information system to see if the spare parts are in stock. It is very important to check whether the parts are reserved for production. If the spare parts are reserved, they are technically not in stock and cannot be shipped out as spare parts. If the ordered parts are not in stock, this will cause a delay, and the supplier must therefore negotiate with the customer as to whether or not the delay is acceptable. If it is acceptable, the purchasing department buys the required part; if not, the supplier and the customer must either negotiate a solution or the order will be terminated.

The supplier then checks with the logistics department to see if the ordered goods can be shipped to the customer within the requested time. If this is not feasible, the supplier must check with the customer to see whether or not a proposed delay is acceptable. If not, the order will be terminated, but if the part is in stock and can be shipped within the requested time, the shipping department will create a consignment with a transportation company that will receive the shipping details, such as the shipping number (to track the shipment) and shipping labels. The warehouse then packs and labels the consignment and creates the necessary transport documentation. The transportation company then picks up the consignment and ships it to the customer. This consignment process is the same for standard orders, but the difference is that rush orders are packed and shipped the same day. Figure 6 shows how rush orders involving product fabrication are handled.

As mentioned above, the main difference from the spare parts process is that fabrication must be carried out to complete the order. The supplier must therefore check the capacity of the production department, the availability of parts, and whether the order can be shipped to the customer within the required time. If these criteria can be met, the production department fabricates the order. This implies that shortening the timeframe is difficult to control in relation to time standards, since fabrication times may vary. A rush order for parts requiring fabrication involves prioritising this production and then ensuring rapid logistics.

\subsection{Customer Viewpoints}

All the dealerships felt that they had a good relationship with the supplier. In terms of the service provided, they all felt that the supplier was helpful if something really urgent was needed. They also shared the same views on communication and information sharing with the supplier, expressing satisfaction with their relationship with the supplier. The following provides more details of the operations associated with rush orders and the administrative and technical processes, which are interrelated. The domestic retailers are discussed first, followed by international representatives.

\subsubsection{Domestic Retailers' Concerns}

It is important to differentiate between new production and warranty cases, and to understand that not all rush orders are the same. However, when a customer decides to purchase a sanitary product, they want it to be installed as soon as possible, thereby creating a rush order or a request for quick delivery. A toilet facility is essential, and a customer cannot go for long without functioning toilet facilities. In the process of building a cabin, the customer might need to order parts within a very short time. A breakdown in the sanitary system is one of the main drivers for rush orders; a critical situation can arise quickly when the system does not work, leading to a sense of urgency for the customer, and this is passed on to the dealer, who may trigger a rush order. In situations where a sanitary system is not working, there is sometimes no other choice but to place an order and customers will accept paying the price that is set.

Although the supplier could justify charging a fee for handling a rush order from a cost standpoint, this is not recommended based on the supplier's responsibility to their dealers and end-users, since it could be perceived as greedy. Creating rush orders depends on when the customer placed an order and when the customer expects to receive it. One informant said:

One example could be that the customer contacts us and does not understand the time it will take to make the sanitary system and send it - the customers don't know how the system is made or that some of the parts need to be made from scratch. There is clearly a problem in that the customer needs to understand how this product is made, so that they can actually prevent rush orders from arising.

Human error can also cause rush orders. In addition, the logistics may not be able to handle many customers, a hectic schedule and bad planning, all of which can cause rush orders. The informants also mentioned that getting the right information from customers can cause rush orders, but they argued that the customers did not all have the information they needed. One customer stated:

Another problem concerning rush orders may be that we have forgotten to put an order we have received from a customer at a cabin booth event into our system. So, the customer calls us and asks where the system is that he/she ordered three weeks ago. Since we have promised the customer to deliver the system within a certain date, we 
would need to handle it as a rush order, which creates huge stress for us and for our supplier.

Inventory is not kept, unless it is critical for the functionality of the sanitary system. Most of the time, they only keep essential spare parts in stock, but often feel that they cannot protect themselves against every single breakdown, since it is very difficult to anticipate which parts to keep in stock to be able to serve their customers. Knowledge of the sanitary system is essential, since without this knowledge, it is difficult for some dealerships and customers to understand which parts could be beneficial to have in stock. Demand plays an important role in terms of knowing which spare parts to have in stock, as it can vary according to the different months in a year. Spare part stock is also influenced by cost, since the company does not want to bind up too much capital in the stock. Customers are sceptical of paying additional fees for rush orders. One customer stated:

Charging for the service would damage our relationship with the end users. Although the system is easily constructed, it requires special expertise to resolve certain issues. It is vital that we as a dealer and end user can get help outside of normal working hours, without this having to be paid for. Imposing a fee for placing a rush order would probably help the supplier to create a barrier against incoming rush orders that are really not rush orders. It won't be them as a dealer who will need to pay for it; it would be their customers.

This customer highlights the need for improved communication with the supplier and their own customers, in order to better inform their customers about how long an order could take and which parts need to be produced. Another informant said:

One could argue for the use of a fee to interfere and maybe reduce the incoming amount. It could also help to sort out which orders really are rush orders, and which are not.

Rush orders can be better handled by offering a service package with the most crucial parts. One informant stated:

By offering a service package, we could respond better and faster, and lower the risk of creating a rush order.

Another informant stated:

Something that could help us do our job better would be if we had a list of parts and part numbers. When we have used one of the parts, we could easily reorder new ones.

\subsubsection{Representatives' Concerns}

Rush orders are placed because customers do not plan ahead in terms of which spare parts they will need. Rush orders could be avoided if the customer were to check and plan for the spare parts that will be required over one year; if the ships did this, there would be no need for rush orders. If customers have an urgent need for parts but do not order them until the last minute, this creates a huge stress on the system, since the parts are needed before the ships sail. The potential savings would be involve avoiding the rerouting of the vessel and its costly downtime. Communication from the customer could sometimes be challenging for the representatives. They mentioned that the customers usually provided the shipping details only when they received notice of the order being ready and the packing details. There are differences related to the sizes of the customers, in that smaller companies do not have strict service procedures for their sanitary systems. One effect of this may be that the sanitary system wears down more quickly over time compared to those of the larger customers. The system eventually breaks down, so the customer must then place a rush order. Other problems in relation to rush orders included cases where the customers needed spare parts, but not urgently. One representative had seen miscommunication in which customers indicated urgency in the subject line of an email.

Other potential causes for rush orders could include a lack of knowledge about the problem. The customers do not pay attention to sanitary systems, and the representative's attempts to educate them have been fruitless. This is normally not due to a lack of information but a lack of willingness on the part of customers, who do not plan and do not place orders in good time. The representatives try their best to avoid misusing the good service they get from the supplier, but they will place a rush order if necessary, trusting that the supplier will provide what they need in time and that the customer support service will be excellent. Some of their customers keep a stock of spare parts on the ship, but not in their warehouses. As one representative stated:

Our customers don't want to hold any stock of spare parts that is not urgently required, since they don't wish to spend money on it. We keep some spare parts, but most of them are now outdated.

Another representative stated:

Recently, we had an experience in relation to spare parts for a main engine. A company with six vessels was trying to find about 4,000 USD to order the goods. By the time the money had been collected, they needed the spare parts that should have been sent weeks ago, within a few days, and created a rush order. It is the Greek mentality to not keep spare parts on board the ships.

Some spare parts are held in stock by the international representatives, but if they do not have a part in stock, they contact the supplier to create a new purchase order. The reason for not keeping all the different spare parts in stock is because the patterns of demand are too volatile, and the risk of the parts becoming outdated is high. The supplier is therefore afraid of tying up too much capital. The representatives stated that the supplier had too many types of spare parts, making it logistically challenging and difficult to keep track of them. They also mentioned that they did not have access to the parts database linked to each customeroperated vessel. The parts they did have in stock were mostly outdated. Furthermore, the representatives argued that money was not an issue for their customers, and that they only placed a rush order when they urgently needed something. In terms of rush order fees, one representative argued that it would be difficult for their customers to accept such a fee if there was no guarantee that their parts would arrive on time. This is difficult for the customer to guarantee, since there will always be a risk of delays.

\section{ANALYSIS}

\subsection{The Causes of Rush Orders}

It is almost impossible to plan for rush orders, which makes it difficult to predict the time thresholds and how they will affect normal operations. They are embedded in a network of reciprocally interdependent relationships. The supplier has many customers, and in the same way, the customers have many suppliers and many varying facilities 
demanding the spare parts. This is not a simple linear planning problem, especially given that the need for spare parts emerges suddenly and without warning. It is difficult to envision any form of planning that would rule out the necessity of the supplier managing these supplies in an efficient and effective way. Rush orders represent the everyday reality of production in the case study company.

The company in the case example has no clear concept of rush orders, and has not classified what defines a rush order; it is simply a service they provide to their customers. It is also difficult to define a rush order since there are different degrees of urgency compared to other orders. There seems to be no clear borderline, but rather a continuum regarding time constraints. The distinction of what defines a rush order in the supply chain becomes increasingly unclear when we consider orders that need to be fabricated. These orders must be produced in the factory, which takes time. Rush orders are prioritised above standard orders, implying that they do not follow the standard time guidelines applied to in-stock spare parts. A limited conceptual understanding of what a rush order actually is and what differentiates it from a standard order also hampers an understanding of the causes of rush orders.

Customers have the fullest understanding of the causes of rush orders, as described in the customer interviews. Many of the incoming rush orders were a direct consequence of their dealers and representatives failing to keep stock of the most important parts, which could help to reduce the demand uncertainty. In 2016, approximately $8 \%$ of the orders received by the supplier were rush orders, which disturb the normal production process and can cause delays. Companies that make innovative products tend to be particularly affected by their customers' volatile order horizons, and this was the case for the supplier for many years. Most of the time, it produces custom orders, which have a very high uncertainty level. However, the supplier also offers some products as stock items, which have a low uncertainty level, and this differs in terms of the segment for which they are made. The ship and offshore segment has greater uncertainty, due to the fact that most products for this segment are made to fit custom-designed installations, while the land and transportation segment, in which five to six standard products are used, has a lower uncertainty level.

\subsection{Effects of Rush Orders}

Regarding the service provided to customers, the supplier has no clear set of standards to explicitly define the service level they are providing to their customers. Their customers set the service level in terms of customer requirements, but by heeding these customer requirements, the supplier sets the ideal service level at $100 \%$. This is clearly more a motivating aim than a realistic practicality. It also seems that the supplier has not been able to handle the transition to being an innovator in the sanitary system market, and has gone from only a few customers to possibly now too many. Providing excellent service to a few customers is manageable, but complexity increases as the supply system grows, rendering it increasingly difficult to plan and manage in accordance with pre-set supply processes.

The empirical findings also suggest that the dealers and representatives are very satisfied with the supplier's service, and that they receive a quick response when they need help with something. A technical issue with an installed sanitary system is a common cause of a rush order, and the supplier then responds with a willingness to fill their customers' need for quick service. This may be one of the underlying reasons why the supplier has a problem with rush orders, as they appear to push the rush order service by agreeing to rush orders that could have been sent as standard orders. This also implies organisational consequences, as resources could be more economically used if an order that is not critical can be shipped using standard ordering procedures.

Some representatives or dealers also tend to send requisitions too late, meaning that a rush order becomes an emergency through exchange process timing. This causes enormous stress on the supplier's production system. Sharing information regarding production and delivery times could prevent these rush orders, with customers stating their spare parts needs at an earlier stage. A lack of the right information at the right time seems to be a problem for both the supplier and their representatives and dealers, and means that they are unable to create a responsive supply chain. This is an example of discrepancies associated with the exchange economy (Hammervoll, 2014). According to Svensson and Barfod (2002), a rush order is often characterised as something that must be fabricated as soon as possible because a certain type of part was not in stock. This supports a statement by one of the customers. Parts may be needed within a very short timeframe so as not to delay the overall building process of a cabin, for example. This is also the case in shipbuilding, where the supplies must be coordinated with the overall construction process. In such cases, the supply is organisationally networked, and must be supplied in a timely manner in relation to previous and subsequent activities at the construction site (Engelseth and Zhang, 2012). Yan-Hai (2005) argues that having the right documentation at the right time is crucial for proper planning in such complex network scenarios. If the supplier does not plan adequately, this can lead to the creation of rush orders. In this case, the communication between the supplier and their customers was good, with a sufficient degree of established trust, and the transactions described here are recurring encounters. However, there were sometimes problems with communication, which could cause rush orders based on a form of misunderstanding rather than a lack of formal documentation.

\subsection{Solutions to Rush Orders}

Eliminating all rush orders from occurring is not likely to be realistic for this supplier, and some of the effects of rush orders are difficult to solve. However, we propose some solutions to lower the number of rush orders and handle them in a way that can ease their adverse effects. Our empirical findings show that some solutions were already in place, but that there was also the potential to find more. The retailers and foreign representatives also provided some solutions. Davis (1993) and Wang and Chen (2008) argue that using inventory can be a solution that can both prevent rush orders and smooth the variation in supply and demand. Some retailers and representatives have inventories with spare parts. Our findings show that inventories of finished products/systems are organisationally challenging, due to the variation in orders and the lack of standardisation. The 
resources are only weakly integrated, and are therefore difficult to pool. Some finished products are available in the land and transportation segment, but there is great variation in the ship and offshore segment. Wang and Chen (2008) also argue that suppliers should reserve management and production capacity, as this could help in coping with rush orders. The supplier has attempted to do this and has stated that employees will work overtime if necessary. However, risk of keeping inventory and reserving capacity is that they will not be used, and that money will be wasted (Wang and Chen, 2008).

Solutions for coping with demand uncertainty include postponement, information sharing, buffer stocks, and leadtime management (Davis, 1993). Postponement involves accepting delays, which would mean negotiating with the customer to accept waiting for an order that may be critical by an agreed-upon time. Variation in demand is uncertain, meaning that it is difficult to predict rendering and planning. It is possible to hold extra inventory (buffering) in order to keep rush orders under control; since the supplier does not know when unexpected repairs will be necessary, buffer stocks would safeguard against a meltdown in the system. Customers also experience intermediaries, so demand is volatile and often unexpected.

Lead-time management could help in handling the level of uncertainty by allowing the representatives and dealers to create a space between the actual time it takes and what their customer knows. This would help the supplier to handle rush orders within a reasonable time. Unplanned orders such as rush orders would be a direct cause of variation in lead times as the backlog increases and the work in progress goes up and down (Kim and Duffie, 2004). Lead-time management means using flexible organisational and technical resources to cut down the time of delivery of unplanned orders. The focus should be directed toward developing production flexibility to reduce the lead time in urgent situations (Chapman, 2006). This would involve flexibility in both logistics and fabrication, and developing efficient processes to manage production (logistics and fabrication) flexibility, thus demanding effective information systems. Key to this development is the use of product and information standards in unison to facilitate efficient and effective resource pooling.

The supplier's idea of introducing a rush order fee was discussed with the customers. Unsurprisingly, the customers' immediate thought was that the fee aimed to cover some of the costs of offering a high level of service, which was starting to cost a substantial amount of money.
This fee would elevate organisational awareness of rush orders and motivate customers to avoid them. The interviews with customers showed clearly that improved interaction between the suppliers and their customers could help reduce supply uncertainty, and could create orders in a standardised information format, thus easing interpretation and further ordering. Introducing a fee could be helpful in terms of eliminating some rush orders that were not in fact urgent. A rush order fee could also solve the issue of all orders being communicated as rush orders, even when they are not. The findings from the interviews with the retailers and the representatives did not provide a clear indication of whether or not the number of rush orders would decrease if an order fee was imposed. The majority of the customers were negative toward introducing such a fee, and it could have negative effects on relationships with the supplier.

\subsection{Conceptual Model}

Our findings are summarised in the conceptual model shown in Figure 7.

The model presents an array of solutions mentioned both in the literature and by the informants. This study has not considered the degree to which the solutions are coordinated efforts, and whether this set of policies contains procedures that may conflict with each other. The literature review involved a search for how a complex, systems-based form of thinking may help in organising the efficient and effective handling of rush orders. The main statement made here is that complexity represents a higher level of analytical abstraction. These solutions are a complex phenomenon and can therefore be modelled using agent-based rules applied at a micro-process level. "Complexity" itself is not the major problem; our understanding that complexity is the prime characteristic of the handling of rush orders by the studied networks directs attention to the design of managerial procedures to cope with rush orders as emergent processes, from the moment the demand is incurred until the customer's problem is solved. Based on the empirical findings from this single case study, we suggest that one solution for effectively and efficiently handling rush orders would entail designing this form of exchange and supply as a complex system.

Figure 8 represents the considerable complexity of the interactions that are implicitly described in Figure 7. We note that Figure 8, which is drawn in a planar graph fashion, could certainly be improved upon to better reflect the reality of the problem. This could be attempted after agent-base modelling and simulation is conducted, for example. 


\section{Rush Orders}

\begin{tabular}{|c|c|c|}
\hline & Causes & \\
\hline $\begin{array}{l}\text { Lack of knowledge } \\
\text { about the sanitary } \\
\text { system } \\
\text { Human errors } \\
\text { Lack of planning } \\
\text { regarding procurements }\end{array}$ & $\begin{array}{l}\text { - Communications } \\
\text { problems/lack of } \\
\text { information about lead- } \\
\text { times } \\
\text { - Problem with shipment } \\
\text { - Cultural differences }\end{array}$ & $\begin{array}{l}\text { Change in customer } \\
\text { orders/request for fast } \\
\text { delivery } \\
\text { - Lack of spare parts } \\
\text { inventory } \\
\text { - Unplanned repairs }\end{array}$ \\
\hline
\end{tabular}

\begin{tabular}{|c|c|c|}
\hline & Effects & \\
\hline $\begin{array}{l}\text { Provoke or delays } \\
\text { standard orders } \\
\text { - Lead times to vary } \\
\text { - Increase backlog } \\
\text { - Work in progress vary } \\
\text { - Causes difficulties in } \\
\text { forecasting } \\
\text { - Creates a stressful work } \\
\text { environment }\end{array}$ & $\begin{array}{l}\text { - Could decrease service } \\
\text { level on standard orders } \\
\text { - Increase cost of delay } \\
\text { - Increase } \\
\text { unpredictability of the } \\
\text { production system } \\
\text { - Creates a stressful work } \\
\text { environment }\end{array}$ & $\begin{array}{l}\text { Causes rearranging of } \\
\text { scheduled plan } \\
\text { - Could affect the } \\
\text { relationship between } \\
\text { new and existing } \\
\text { customers } \\
\text { - Creates high demand } \\
\text { uncertainty } \\
\text { - Increased service costs }\end{array}$ \\
\hline & Solutions & \\
\hline $\begin{array}{l}\text { Use inventory to } \\
\text { smooth out the } \\
\text { variation } \\
\text { - Rush order fee } \\
\text { - Share knowledge about } \\
\text { the systems }\end{array}$ & $\begin{array}{l}\text { - Adjust work in progress } \\
\text { level } \\
\text { - Safety stock with spare } \\
\text { parts } \\
\text { - Reserve production } \\
\text { capacity }\end{array}$ & $\begin{array}{l}\text { Information sharing } \\
\text { with downstream } \\
\text { partners } \\
\text { - Production flexibility }\end{array}$ \\
\hline
\end{tabular}

Figure 7 Causes, effects, and solutions related to rush orders 

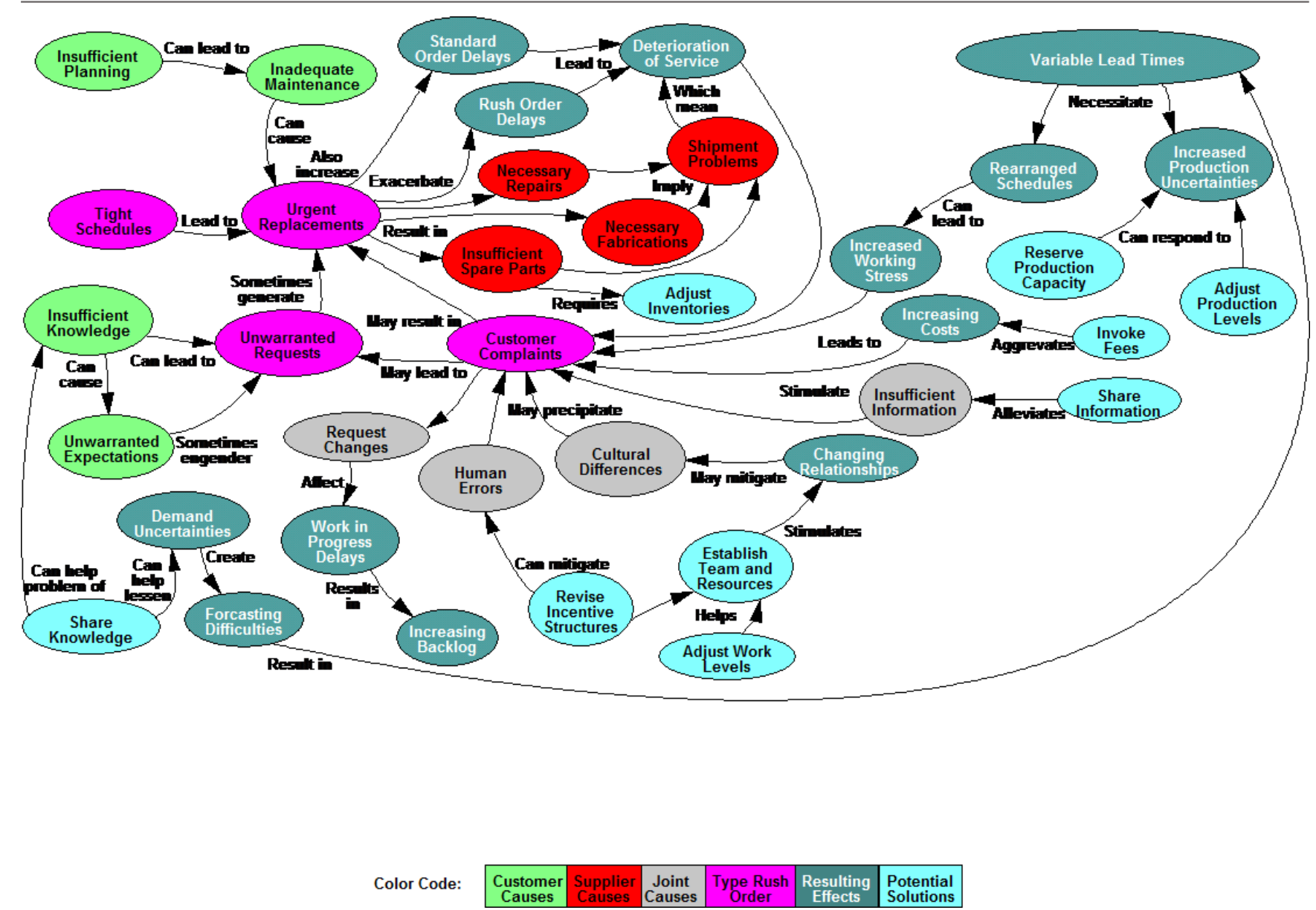

Figure 8 Some of the interaction complexities of the rush orders in Figure 7

\section{CONCLUSION}

The contribution of this study is the empirical grounding of a conceptual model (Figure 8) in rush order management and handling in order to provide a conceptual foundation for further studies of this real business challenge. Research is needed that probes deeper into how to manage rush orders as a complex system, which may include more detailed conceptual modelling and simulation. In particular, agent-based modelling and associated and informed trialand-error simulations based on variations in the rules governing agent behaviour can lead to good solutions. Information technology software associated with interconnectivity can be especially beneficial here, and would support the real-time connectivity of actors, documents, and a huge variety of things (goods, facilities, tools etc.). Information technology software that treats rush order processing as a complex system may be developed, implying a form of decentralised planning in which decisionmaking can be automated based on updated real-time interaction. However, since complex systems are difficult to predict, it is not clear what role forecasting should play in this scenario. It is possible that planning procedures could be used to design the long-term context for the resources used to handle these rush orders. The interaction with the strategic network of resources, the task environment, and the actual process of handling rush orders as a process should also be studied. This may involve simulating various network configurations as the context for improved rush order supply processes.

\section{ACKNOWLEDGEMENTS}

Data collection and initial analysis work was carried out by Vegard Pettersen and Inge Finnes Saunes, both former students at Molde University College, Molde, Norway. A shorter version of this paper, "The Networked Handling of Rush Orders", is included in the proceedings of the 2019 OSCM conference in Ho Chi Minh City, Vietnam.

\section{REFERENCES}

Angkiriwang, R., Pujawan, N., and Santosa, B. (2014). Managing uncertainty through supply chain flexibility: Reactive vs. proactive approaches. Production and Manufacturing Research 2 (1), pp. 50-70.

Blackenfelt, M. (2001). Managing complexity by product modularization. Doctoral thesis. Department of Machine Design, Stockholm Sweden Royal Institute of Technology, No. 1.

Chen, C.-L. (2010). A heuristic model for justifying the acceptance of rush orders in multi-plants manufacturing supply chain with outsourcing. 8th International Conference on Industrial Informatics (pp. 607-611). Osaka: INDIN 2010.

Chopra, S., and Meindl, P. (2010). Supply Chain Management (4th ed.), Prentice Hall, New Jersey.

Closs, D., Jacobs, M., Swink, M., and Webb, G. (2008). Toward a theory of competencies for the management of product complexity: Six case studies. Journal of Operations Management 26 (5), pp. 590-610.

Cooper, M.C., Lambert, D.M., and Pagh, J. (1997). Supply chain management: More than a new name for logistics. International Journal of Logistics Management, 8 (1), pp. 114. 
Davis, T. (1993). Effective supply chain management. Sloan Management Review, 34 (Summer), pp. 35-46.

Eisenhardt, K.M. (1989). Building theories from case study research. Academy of Management Review, 14 (4), pp. 532550.

Ehteshami, B., Petrakian, R.G., and Shabe P.M. (1992). Trade-off in cycle time management: Hot lots. IEEE Transactions on Semiconductor Manufacturing, 5 (2), 101-105.

Ellram, L.M. (1996). The use of the case study method in logistics research. Journal of Business Logistics, 17 (2), pp. 93-138.

Engelseth, P. and Zhang, Y. (2012). Engineering roles in global maritime construction value networks. International Journal of Product Development 17, pp. 254-278.

Fortuin, L. and Martin, H. (1999). Control of service parts. International Journal of Operations and Production Management 19 (9), pp. 950-971.

Gourdin, K. (2006). Global Logistics Management (2nd ed.), Blackwell, Malden, MA.

Halldorsson, A., Kotzab, H., Mikkola, J.H., and Skjoett-Larsen, T. (2007). Complementary theories to supply chain management. Supply Chain Management: An International Journal 12 (4), pp. 284-296.

Halldorsson, A., Kotzab. H., and Skjott-Larsen, T. (2003). Interorganizational theories behind supply chain management discussion and applications. In S. Seuring, M. Müller, M. Goldbach and U. Schneidewind (Eds.), Strategy and Organization in Supply Chains, Berlin, Physica Verlag.

Hammervoll, T. (2014). Service provision for co-creation of value: Insights from exchange- and production-economy perspectives. International Journal of Physical Distribution and Logistics Management 44, pp. 155-168.

Huiskonen, J. (2001). Maintenance spare parts logistics: Special characteristics and strategic choices. International Journal of Production Economics 71, pp. 125-133.

Ketchen Jr., G. and Hult, T.M. (2006). Bridging organization theory and supply chain management: The case of best value supply chains. Journal of Operations Management 25 (2), pp. 573580.

Kim, J. and Duffie, N. (2004). Backlog control design for a closed loop PPC system. CIRP Annals - Manufacturing Technology 53 (1), pp. 357-360.

Kouvelis, P., Chambers, C., and Wang, H. (2006). Supply chain management research and production and operations management: Review, trends, and opportunities. Production and Operations Management 15 (3), pp. 449-469.

Lichtenstein, B.B. (2014), Generative Emergence, Oxford University Press, Oxford, UK.

Lincoln, Y.S. and Guba, E.G. (1985). Naturalistic Inquiry, Sage Publications, Newbury Park, CA.

Mentzer, J.T., DeWitt, W., Keebler, J.S., Min, S. Nix, N.W. Smith, C.D. and Zacharia, Z.D. (2001). Defining supply chain management. Journal of Business Logistics 22 (2), pp. 1-25.

Meredith, J. (1998). Building operations management theory through case and field research. Journal of Operations Management 16(4), pp. 441-454.

Plossl, G.W. (1973). Manufacturing control: The last frontier for profits, Reston, VA, Reston Publishing Co.

Rzevski, G., and Skobelev, P. (2014). Managing Complexity, WIT Press, Southampton UK.

Simangunsong, E., Hendry, L-C., and Stevenson, M. (2011). Supply chain uncertainty: A review and theoretical foundation for future research. International Journal of Production Research 50 (16), pp. 4493-4523.

Svensson, C. and Barfod, A. (2002). Limits and opportunities in mass customization for "build to order" SMEs. Computer Industry 49 (1), pp. 77-89.

Thomas, G. (2011). How To Do Your Case Study. Sage, London.

Thompson, J.D. (1967). Organizations in Action. McGraw Hill, New York.

Trzyna, D., Kuyumcu, A., and Lödding, H. (2012). Throughput time characteristics of rush orders and their impact on standard orders. Procedia CIRP 3, pp. 311-316.

Voss, C., Tsikriktsis, N., and Frohlich, M. (2002). Case research in operations management. International Journal of Operations and Production Management 22 (2), pp. 195-219.

Wang, W. and Chen, Z. (2008). A neuro-fuzzy based forecasting approach for rush order control applications. Expert Systems with Applications 35 (1-2), pp. 223-234.

Yan-Hai, H., Jun-Qi, Y., Fei-Fan, Y., and Jun-He, Y. (2005). Flow shop rescheduling problem under rush orders. Journal of Zhejiang University-SCIENCEA 6 (19), pp. 1040-1046.

Yao, J. and Liu, L. (2009). Optimization analysis of supply chain scheduling in mass customization. International Journal of Production Economics 117 (1), pp. 197-211.

Yin, R. (2003). Case Study Research (3rd ed.), SAGE Publications, London.

Per Engelseth is professor in logistics at University of Troms $\varnothing$. He received his Dr. Oecon degree from BI Norwegian Business School in 2007. His main research interests include, case studies of end-to-end food supply chains, food product traceability, engineering management, supply chain collaboration including value co-creation, local foods supply chains, complex adaptive systems and now more recently he is involved in research on management in healthcare service systems. He has published numerous articles in academic journals as well as in anthologies.

Brian E. White received Ph.D. and M.S. degrees in Computer Sciences from the University of Wisconsin, and S.M. and S.B. degrees in Electrical Engineering from M.I.T. He served in the U.S. Air Force, and for 8 years was at M.I.T. Lincoln Laboratory. For 5 years Dr. White was a principal engineering manager at Signatron, Inc. In his 28 years at The MITRE Corporation, he held a variety of senior professional staff and project/resource management positions. He has been Adjunct Professor at several U.S. universities as well as offering consultancy services. He has edited and authored several published books and book chapters. 